\title{
MENINGKATKAN KEMAMPUAN KOGNITIF DENGAN METODE EKSPERIMEN PADA ANAK USIA 3 - 4 TAHUN DI PAUD AZ- ZAITUN GENTING TANAH TAHUN PEMBELAJARAN 2018/2019
}

\author{
Martina \\ PG PAUD Universitas Widya Gama Mahakam Samarinda \\ martianapaud@gmail.com \\ Hanita \\ PG PAUD Universitas Widya Gama Mahakam Samarinda \\ nitahanita87@gmail.com
}

\begin{abstract}
Abstrack
This study aims to find out how the experiment method in improving student's understanding on concept of weight for students aged 3 to 4 . This study was conducted in Az-zaitun Genting Tanah Pre-school. The research subjects were twelve students of group $B$ aged three to four, consisting of five males and seven females. The researcher applied classroom action research with two cycles, applying four stages; planning, implementation, observation and reflection.

The result shows that students' understanding on weight concept has increased. At the first cycle, students' understanding reached $36 \%$ and increased into $79 \%$ at the second cycle. In conclusion, the experiment method is effective in improving students' understanding on weight concept. Therefore, it is suggested that teacher to give stimulation and practice for improving students' understanding weight concept.
\end{abstract}

Key words: Understanding on Concept of Weight, Experiment Method, Students Aged Three to Four 
Jurnal Warna : Jurnal Pendidikan Dan Pembelajaran Anak Usia dini. Maret 2019. Vol 04. No. 01

PENDAHULUAN

Peraturan Menteri Pendidikan dan Kebudayaan Republik Indonesia Nomor 137 tahun 2014 tentang Standar Nasional Pendidikan Anak Usia Dini Bab 1, pasal 1, butir 10, menyatakan bahwa pendidikan anak usia dini adalah upaya pembinaan yang ditujukan kepada anak sejak lahir sampai usia 6 (enam) tahun yang dilakukan melalui pemberian rangsangan pendidikan untuk membantu pertumbuhan dan perkembangan jasmani dan rohani agar anak memiliki kesiapan dalam memasuki pendidikan lebih lanjut (نوروزى 1388). Pendidikan anak usia dini perlu diperhatikan untuk mengoptimalkan seluruh potensi yang dimiliki oleh anak.

Anak dengan usia 3-4 tahun termasuk dalam tahap potensial dimana tahapan ini anak telah menunjukan aktivitas proses berpikir yang sangat aktif, sudah dapat memahami kejadian yang ada disekitarnya dengan menggunakan tandatanda dan simbol. Lingkungan merupakan salah satu faktor yang mempengarui kreativitas seorang anak. Maka perlunya lingkungaan dirancang sedemikian rupa supaya dapat mengembangkan dan menyempurnakan kemampuan anak yang dibawa sejak lahir dan pengembangan kemampuan kreativitas anak sangat penting dikembangkan oleh Guru.(Pendidikan et al. 2017)

Peraturan Menteri Pendidikan Nasional N0. 58 tahun 2009 menyatakan bahwa Pengembangan pembelajaran kognitif pada anak usia dini memiliki peranan sangat penting . Salah satu pengembangan kemampuan kogintif pada anak usia dini adalah mengembangkan kemampuan memahami konsep ukuran. Konsep ukuran yang dapat dipelajari anak usia dini diantaranya berupa volume, berat, ringan, panjang atau jarak, dan waktu dengan tujuan agar anak mempunyai keterampilan dalam mengukur suatu benda. Cara untuk memahami konsep ukuran salah satunya berat ringan dapat dilakukan dengan cara membandingkan dua benda yang memiliki ukuran dan bentukyang berbeda. Fungsinya agar dapat melatih anak dalam menghubungkan sebab akibat dan hasilnya akan nampak secara langsung. Kegiatan eksperimen dengan kegiatan pembelajaran maupun bermain dapat diguakam sebagai sarana dalam mempelajari Pengetahuan mengenai konsep ukuran sederhana. Cara pembelajaran yang melibatkan anak dengan mengalami dan membuktikan sendiri proses dan hasil percobaan disebut dnegan Metode eksperimen. Metode eksperimen adalah cara menyajikan pembelajaran dengan menggunakan dan menyajikan pembelajaran, dimana anak melakukan percobaan dengan mengalami dan membuktikan sendiri sesuatu yang dipelajari (Djamarah dan Aswan, 2006:84) dalam (Pendidikan et al. 2017) 
Jurnal Warna : Jurnal Pendidikan Dan Pembelajaran Anak Usia dini. Maret 2019. Vol 04. No. 01

Pengukuran biasa digunakan dalam kehidupan sehari hari seperti ukuran panjang, berat dan isi, disetiap satuan ukuran dibagi menjadi beberapa tingkat yaitu terkecil ke yang besar dari pendek ke panjang serta dari ringan ke yang berat.

Kegiatan penetahuan ini perlu diterapakan kepada anak usia dini sebagai salah satu stimulus meningkatkan kemampuan kognitif anak didik sehingga dapat memahami dan dipergunakan pada kehidupan sehari hari (Kemampuan et al. 2016). Berdasarkan konsep dan keterampilan dalam kegiatan mengukur, anak didik melalukan kegiatan untuk mendeskripsikan dan membandingkan ukuran, seperti panjang dan berat. Terdapat 3 macam perbandingan yang dapat membantu anak dalam mengembangkan konsep ukuran, yaitu membandingkan dua, membandingkan dua benda yang berdekatan secara langsung dan membandingkan dua objek secara tidak langsung, yaitu dengan menggunakan 3 benda.(نوروزى 1388)

\section{Penerapan Metode eksperimen} melalui bermain sebagai cara belajar anak merupakan upaya mencukupi kebutuhan anak. Bermain dapat memenuhi kebutuhan anak secara aktif terlibat dengan lingkungannya, untuk bermain dan bekerja dalam menghasilkan suatu karya, serta memenuhi tugas-tugas perkembangan kognitif lainnya. Saat anak bermain, anak menerima pengalaman baru, memanipulasi bahan dan alat, berinteraksi dengan orang lain dan mulai merasakan dunia mereka serta dalam keadaan yang menyenangkan. Konsep sains Anak memperoleh pengetahuan melalui pengoptimalan panca inderanya atau sensorinya, anak dapat melihat bayangan yang ditangkap oleh matanya, anak dapat mendengarkan bunyi melalui telinganya, anak dapat merasakan panas dan dingin lewat perabaannya, anak dapat membedakan bau melalui hidung dan anak dapat mengetahui aneka rasa melalui lidahnya.(Lestariningrum and Nuryanti 2016)

Adapun saat ini, berdasarkan pengamatan yang dilakukan pada anak dengan usia 3-4 tahun di PAUD Az-zaitun Genting Tanah aspek perkembangan kognitif anak tentang konsep ukuran berat ringan masih cukup rendah. Hal tersebut terlihat pada kegiatan salah satunya membandingkan berat ringan dua benda berdasarkan jenisnya tanpa bantuan alat timbangan yaitu dalam hal ini digunakan buku tulis dan 1 lembar kertas, dimana terdapat beberapa anak yang masih terlihat bingung saat menyebutkan dan membandingkan antara benda yang ukurannya lebih berat dan yang lebih ringan serta beberapa anak yang masih perlu dibantu dalam menjawab. Oleh karena itu, dapat dikatakan bahwa kemampuan memahami konsep berat ringan anak pada anak usia 3-4 tahun di PAUD Azzaitun belum terlalu berkembang 
Jurnal Warna : Jurnal Pendidikan Dan Pembelajaran Anak Usia dini. Maret 2019. Vol 04. No. 01

disebabkan karena kegiatan dalam mengasah keterampilan konsep ukuran sendiri jarang dilakukan baik itu dengan menggunakan alat timbangan sederhana maupun tanpa menggunkan alat.

Masalah yang timbul dalam pembelajaran tentang pemahaman konsep ukuran berat ringan tersebut tentu perlu adanya alternatif pemecahan. Salah satu alternatif pemecahan yang dapat dilakukan adalah menggunakan metode pembelajaran yang mampu memberikan kesempatan kepada anak untuk menemukan sendiri dan mengkonstruksi suatu konsep. Hal tersebut dapat dicapai melalui penerapan metode eksperimen karena metode eksperimen dapat menjadikan kegiatan pembelajaran mengasyikan dan bermakna, dialami anak secara langsung serta hasil kegiatan belajar anak bisa dengan mudah diamati langsung oleh pendidik untuk menilai serta melihat perkembangan kreativitas anak dalam proses belajar.

\section{METODE PENELITIAN}

\section{Prosedur Penelitian}

Desain penelitian ini adalah penelitian tindakan kelas (PTK). Peneliti menggunakan desain ini karena permasalahan yang terjadi dalam proses pembelajaran di kelas (Nopayana et al. n.d.), dan permasalahan tersebut dapat dilakukan perbaikan melalui berbagai tindakan- tindakan tertentu supaya anak mendapatkan konsep yang bermakna dan mencapai titik pemahaman.Prosedur penelitian ini dilakukan dengan metode eksperimen dengan dua siklus dimana tiap siklusnya terdiri dari 4 tindakan dimulai dari tahap perencanaan, pelaksanaan dan pengamatan serta refleksi. Adapun langkah-langkahnya sebagai berikut :

\section{Siklus}

\section{a. Perencanaan}

Menyediakan perangkat penelitian, meliputi :

1. Rencana pelaksanaan Pembelajaran Harian (RPPH) dan RPPM yang mencakup: Indikator, kegiatan pembelajaran, alat / sumber belajar dan lembar nilai perkembangan anak

2. Menyiapkan berbagai media pembelajaran, yaitu : media kayu balok, gelas berisi pasir, dan neraca sederhana

3. Membuat lembar observasi siswa serta catatan penilaian siswa

\section{b. Pelaksanaan}

1. Kegiatan awal

2. Kegiatan Inti

- Kegiatan ini guru terlebih dahulu menjelaskan secara rinci tentang langkah-langkah cara membedakan konsep berat ringan menggunakan media kayu balok dan gelas berisi pasir. 
Jurnal Warna : Jurnal Pendidikan Dan Pembelajaran Anak Usia dini. Maret 2019. Vol 04. No. 01

- Anak- anak membandingkan berat ringan benda secara mandiri menggunakan neraca sederhana

3. Kegiatan Akhir

Anak diajak berdiskusi bersamasama menilai hasil kegiatan. Memberi motivasi kepada anak yang masih kurang berhasil dan memberi reward kepada anak yang telah baik melaksanakan pekerjaan dengan baik, menyampaikan kegiatan yang akan dilakukan dihari selanjutnya, menutup kegiatan dengan berdoa dan memberi salam.

\section{c. Observasi}

Observasi dilaksanakan selama proses pembelajaran di kelas berlangsung dengan menggunakan lembar observasi yang telah dibuat. Obervasi dilakukan untuk melihat proses kegiatan belajar mengajar secara langsung bagaimana partisipasi siswa pada saat proses pembelajaran berlangsung.

\section{d. Refleksi}

Berdasarkan hasil observasi dan hasil belajar siswa, maka peneliti akan menetapkan :

1. Perkembangan anak yang telah dicapai oleh anak dalam memahami konsep berat - ringan

2. Perkembangan anak yang belum dicapai oleh siswa dalam memahami konsep berat ringan
3. Apa yang perlu diperbaiki dalam siklus berikutnya

\section{Subjek penelitian}

Subjek dalam peneltian ini adalah anak didik dengan usia 3-4 tahun di PAUD Azzaitun Genting Tanah tahun pembelajaran 2018/2019 sebanyak 12 orang anak, yang terdiri dari 7 anak laki-laki dan 5 anak perempuan.

\section{Tempat dan waktu Penelitian}

Lokasi penelitian di laksanakan di PAUD Az-zaitun Genting Tanah pada semester ganjil tahun pelajaran 2018/2019.

\section{Teknik Pengumpulan Data}

Penelitian ini menggunakan teknik pengumpulan data observasi. Observasi dilakukan dengan menggunakan lembar observasi yang telah dipersiapkan dengan cara pemberian skor pada data tersebut kemudian dikuantifikasikan dengan lambang angka yaitu peneliti memberikan angka pada pilihan yang tersedia untuk masing-masing aspek yang akan dinilai. Misalnya dengan : (1) Belum Berkembang), (2) Mulai Berkembang), (3) Berkembang Sesuai Harapan), (4) Berkembang sangat Baik. 
Jurnal Warna : Jurnal Pendidikan Dan Pembelajaran Anak Usia dini. Maret 2019. Vol 04. No. 01

Tabel .1 Indikator Hasil Belajar Peningkatan Pemahaman Konsep BeratRingan Metode Eksperimen

\begin{tabular}{|l|l|l|l|l|l|}
\hline No & Indikator keberhasilan & \multicolumn{3}{|c|}{ Hasil Indikator } \\
\cline { 3 - 5 } & & (1) & (2) & (3) & (4) \\
\hline 1 & $\begin{array}{l}\text { Anak mampu } \\
\text { membandingkan berat- } \\
\text { ringan benda } \\
\text { berdasarkan ukuran } \\
\text { benda }\end{array}$ & & & & \\
\hline 2 & $\begin{array}{l}\text { Anak mampu } \\
\text { membandingkan ukuran } \\
\text { berat-ringan berdasarkan } \\
\text { jenis benda }\end{array}$ & & & & \\
\hline 3 & $\begin{array}{l}\text { Anak mampu } \\
\text { menujukkan hasil berat- } \\
\text { ringan antara balok dan } \\
\text { pasir dengan tepat }\end{array}$ & & & & \\
\hline
\end{tabular}

Keterangan :

BB (1) : Belum Berkembang

MB (2) : Mulai berkembang

BSH (3) : Berkembang Sesuai

Harapan

BSB(4) : Berkembang Sangat Baik

\section{Metode Analisa Data}

Penelitian ini peneliti menggunakan analisis deskriptif kualitatif.Untuk mengetahui tingkat keberhasilan dari penelitian ini menggunakan rumusrata-rata (mean). Rata-rata biasa dinotasikandengan $\mathrm{X}$ adalah rata-rata dari keseluruhan nilai atau jumlah. Rata-rata dihitungdengan menjumlahkan semua data di bagi dengan jumlah datanya. Rumus yangdipakai adalah sebagai berikut :

$$
\mathrm{X}=\frac{\sum N}{\sum n} \mathrm{X} 100 \%
$$

Keterangan :

$\mathrm{N}$ : persentase ketuntasan belajar siswa
$\mathrm{X}$ : Jumlah siswa yang tuntas belajar

$\mathrm{Y} \quad$ : Jumlah siswa keseluruhan

(Anas Sujiono : 2008:43)

Nilai ketuntasan anak dalam memahami konsep ukuran berat ringan anak adalah nilai anak dengan kategori berkembang sesuai harapan (BSH) dengan skor 3, dan berkembang sangat baik (BSB) dengan skor 4, yang menjadi indikator keberhasilan dalam peningkatan pemahaman kognitif anak usia 3-4 tahun di PAUD Az-zaitun.

\section{Indikator Keberhasilan}

Berdasarkan kriteria di atas, maka penelitian tindakan kelas ini dikatakan berhasil dengan baik apabila ada peningkatan pemahaman konsep berat ringan pada anak usia 3-4 tahun di PAUD Az-zaitun melalui kegiatan eksperimen dengan nilai ketuntasan minimal $75 \%$ dengan kategori baik.

Tabel . 2 Tabel Interval Penilaian Hasil

Observasi

\begin{tabular}{|c|c|c|}
\hline No & Presentase & Kriteria Penilaian \\
\hline 1 & $81 \%-100 \%$ & Sangat Baik \\
\hline 2 & $61 \%-80 \%$ & Baik \\
\hline 3 & $41 \%-60 \%$ & Cukup \\
\hline 4 & $21 \%-40 \%$ & Kurang \\
\hline 5 & $0 \%-20 \%$ & Kurang sekali \\
\hline
\end{tabular}

\section{HASIL PENELITIAN DAN}

\section{PEMBAHASAN}

\section{Hasil Penelitian}

\section{Hasil pengamatan siklus 1 Perencanaan}

Tindakan dalam siklus 1 ini dilakukan dalam 3 kali pertemuan, 
Jurnal Warna : Jurnal Pendidikan Dan Pembelajaran Anak Usia dini. Maret 2019. Vol 04. No. 01

perencanaan diawali dengan meminta teman sejawat untuk mengamati pelaksanaan penelitian tindakan kelas berlangsung. Adapun kegiatan siklus 1 pertemuan ke-1 adalah sebagai berikut :

1. Menentukan tema diriku dan subtema identitasku serta topik memperkenalkan diri.

2. Membuat RPPM dan RPPH.

3. Menyiapkan berbagai media pembelajaran yaitu neraca sederhana, pasir dan wadahnya (gelas), kayu balok dan lain-lain.

4. Membuat lembar observasi dan lembar hadir anak.

\section{Pelaksanaan}

Pelaksanaan kegiatan belajar mengajar siklus 1 pertemuan ke-1 dilaksanakan pada hari selasa, 17 juli 2018 di PAUD Az-zaitun pada anak kelompok B usia 3-4 tahun dengan jumlah anak sebanyak 12 orang.

Peneliti menyampaikan materi ukuran berat ringan serta menjelaskan alat neraca sederhana dan cara menggunakannya kemudian memberikan tugas kepada masing-masing anak untuk menyebutkan satu benda disekitar yang berukuran berat dan ringan berdasarkan bentuk ukurannya yaitu besar atau kecil untuk dibandingkan.

Peneliti mempersiapkan media yang akan dipakai untuk penelitian berupa neraca sedehana, gelas dan pasir dan kayu balok, setelah itu menyusun atau memasukkannya kedalam neraca sederhana kemudian anakanak diminta untuk membandingkan ukuran berat ringan antara kayu balok dan pasir tersebut serta menyebutkan hasilnya secara bergantian.

\section{Observasi}

Pada siklus memahami konsep ukuran berat ringan siklus 1 adalah sebagai berikut :

1. Pada siklus 1 pertemuan ke 1 , hasil pengamatan kemampuan memahami ukuran berat ringan dengan kategori berkembang sesuai harapan dan berkembang sangat baik, yaitu mampu membandingkan berat ringan berdasarkan ukuran terdapat 4 anak (30\%), mampu membandingkan ukuran berat ringan berdasarkan jenisnya terdapat 3 anak (25\%) dan mempu menyebutkan hasil ukuran berat ringan antara balok dan pasir terdapat 3 anak (25\%). Maka nilai keberhasilan pada siklus 1 pertemuan ke-1 adalah sebesar $28 \%$.

2. Pada siklus 1 pertemuan ke 2 , hasil pengamatan kemampuan memahami ukuran berat ringan dengan kategori berkembang sesuai harapan dan berkembang sangat baik, yaitu mampu membandingkan berat ringan berdasarkan ukuran terdapat 5 anak (41\%), mampu membandingkan ukuran berat ringan berdasarkan jenisnya terdapat 5 anak (41\%) dan mempu menyebutkan hasil ukuran berat ringan 
Jurnal Warna : Jurnal Pendidikan Dan Pembelajaran Anak Usia dini. Maret 2019. Vol 04. No. 01

antara balok dan pasir terdapat 4 anak

(33\%). Maka nilai keberhasilan pada siklus 1 pertemuan ke-2 adalah sebesar $38 \%$.

3. Pada siklus 1 pertemuan ke 3 , hasil pengamatan kemampuan memahami ukuran berat ringan dengan kategori berkembang sesuai harapan dan berkembang sangat baik, yaitu mampu membandingkan berat ringan berdasarkan ukuran terdapat 6 anak (50\%), mampu membandingkan ukuran berat ringan berdasarkan jenisnya terdapat 5 anak (41\%) dan mempu menyebutkan hasil ukuran berat ringan antara balok dan pasir terdapat 5 anak (41\%). Maka nilai keberhasilan pada siklus 1 pertemuan ke-3 adalah sebesar $44 \%$.

\section{Refleksi}

Berdasarkan hasil pelaksanaan penelitian pada siklus 1 pada pertemuan 1 , 2 dan 3 berdasarkan aspek yang diamati dari 12 orang anak yang mengikuti pembelajaran diperoleh Berdasarkan hasil penelitian tindakan kelas siklus 1, menujukkan bahwa kemampuan anak memahami konsep ukuran berat ringan terus meningkat, namun belum naik secara signifikan, sehingga penelitian akan dilanjutkan pada siklus berikutnya. Adapun hasil penelitian siklus 1 pertemuan ke 1,2, 3 sebagaimana dalam tabel rekaptulasi berikut ini :
Tabel.3 Rekaptulasi Kemampuan Memahami Konsep Ukuran Berat Ringan Siklus 1

\begin{tabular}{|c|c|c|c|c|c|c|}
\hline \multirow{2}{*}{$\begin{array}{l}\mathbf{N} \\
\mathbf{o}\end{array}$} & \multirow[t]{2}{*}{ Nama } & \multicolumn{3}{|c|}{$\begin{array}{c}\text { Aspek } \\
\text { penilaian }\end{array}$} & \multirow{2}{*}{$\begin{array}{c}\text { Jumla } \\
\text { h }\end{array}$} & \multirow[t]{2}{*}{ KT } \\
\hline & & 1 & 2 & 3 & & \\
\hline 1 & Alif & 2 & 2 & 1 & 5 & MB \\
\hline 2 & Zaidan & 2 & 2 & 2 & 6 & MB \\
\hline 3 & Alvinna & 2 & 2 & 2 & 6 & MB \\
\hline 4 & Dzaky & 2 & 3 & 3 & 8 & BSH \\
\hline 5 & Farel & 3 & 2 & 1 & 6 & MB \\
\hline 6 & Kalila & 4 & 3 & 3 & 10 & $\mathrm{BSH}$ \\
\hline 7 & Revi & 3 & 2 & 2 & 7 & MB \\
\hline 8 & Risky & 2 & 2 & 2 & 6 & MB \\
\hline 9 & Najwa & 2 & 2 & 2 & 6 & MB \\
\hline 10 & Selvira & 4 & 3 & 2 & 9 & BSH \\
\hline 11 & Marsya & 2 & 2 & 3 & 7 & MB \\
\hline 12 & Mahafis & 4 & 3 & 3 & 10 & BSH \\
\hline \multicolumn{2}{|c|}{$\begin{array}{c}\text { Jumlah Skor } 3 \\
\text { dan } 4\end{array}$} & 18 & 12 & 12 & \multirow{2}{*}{\multicolumn{2}{|c|}{$35 \%$}} \\
\hline \multicolumn{2}{|c|}{ Persentase } & $\begin{array}{l}41 \\
\%\end{array}$ & $\begin{array}{l}33 \\
\%\end{array}$ & $\begin{array}{l}33 \\
\%\end{array}$ & & \\
\hline & tegori & \multicolumn{5}{|c|}{ Kurang } \\
\hline
\end{tabular}

\section{Keterangan :}

1. $81 \%-100 \%$ : Sangat baik

2. $61 \%-80 \%$ : Baik

3. $41 \%-60 \%$ : Cukup

4. $21 \%-40 \%$ : Kurang

5. $0 \%-20 \%$ : Kurang sekali

Aspek penilaian dan proses pembelajaran siklus 1 sebagai berikut :

1. Peningkatan kemampuan membandingkan berat ringan berdasarkan ukuran mencapai $41 \%$. Hal ini menunjukkan bahwa kemampuan anak memahami konsep berat ringan berdasarkan ukuran berat ringan suatu benda dilihat dari 
Jurnal Warna : Jurnal Pendidikan Dan Pembelajaran Anak Usia dini. Maret 2019. Vol 04. No. 01

bentuknya besar atau kecil melalui kegiatan eksperimen dikategorikan cukup.

2. Peningkatan kemampuan membandingkan ukuran berat ringan berdasarkan jenisnya mencapai $33 \%$. Hal ini menunjukkan bahwa kemampuan anak memahami konsep berat ringan berdasarkan jenisnya dilihat dari jenis bahan benda tersebut misal terbuat dari besi, kayu atau plastik melalui kegiatan eksperimen dikategorikan kurang.

3. Peningkatan kemampuan menyebutkan hasil ukuran beratringan antara balok dan pasir dengan tepat mencapai $33 \%$. Hal ini menunjukkan bahwa kemampuan anak memahami konsep berat ringan dengan menyebutkan hasil ukuran berat ringannya dengan menggunakan neraca maupun tanpa neraca dikategorikan mulai berkembang. Dari hasil pengamatan tabel nilai ketuntasan siklus 1 adalah $35 \%$ termasuk dalam kategori kurang . Hal tersebut dapat digambarkan pada tabel dibawah ini :
Tabel.4 Rekaptulasi Kemampuan Memahami Konsep Ukuran Berat Ringan dengan Metode Eksperimen Siklus 1

\begin{tabular}{|c|l|c|c|c|c|}
\hline No & \multicolumn{1}{|c|}{$\begin{array}{c}\text { Aspek yang } \\
\text { dinilai }\end{array}$} & P1 & P2 & P3 & $\begin{array}{c}\text { Nilai } \\
\text { rata- } \\
\text { rata }\end{array}$ \\
\hline 1 & $\begin{array}{l}\text { Mampu } \\
\text { Membandingkan } \\
\text { berat ringan } \\
\text { benda berdasarkan } \\
\text { ukurannya }\end{array}$ & $\begin{array}{c}\text { \% } \\
\%\end{array}$ & $\begin{array}{c}41 \\
\%\end{array}$ & $\begin{array}{c}50 \\
\%\end{array}$ & $41 \%$ \\
\hline 2 & $\begin{array}{l}\text { Mampu } \\
\text { Membandingkan } \\
\text { berat ringan } \\
\text { berdasarkan } \\
\text { jenisnya }\end{array}$ & $\begin{array}{l}25 \\
\%\end{array}$ & 41 & 41 & $35 \%$ \\
\hline 3 & $\begin{array}{l}\text { Mampu } \\
\text { menyebutkan } \\
\text { hasil ukuran berat- } \\
\text { ringan antara } \\
\text { balok dan pasir } \\
\text { dengan tepat }\end{array}$ & $\begin{array}{l}25 \\
\text { Nilai ketuntasan siklus 1 }\end{array}$ & $\begin{array}{l}\% \\
\%\end{array}$ & $\begin{array}{l}41 \\
\%\end{array}$ & $33 \%$ \\
\hline
\end{tabular}

Hasil pengamatan siklus 1,2 dan 3 dapat digambarkan pada grafik sebagai berikut :

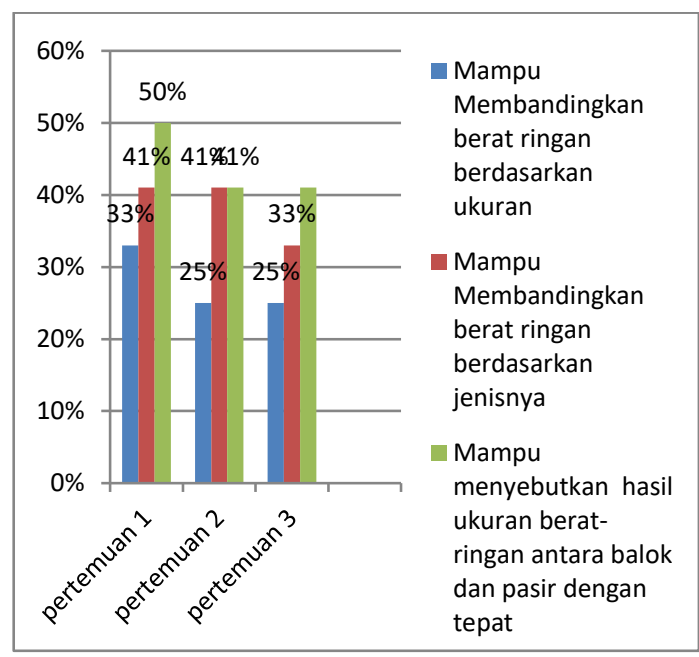

Gambar .1 Grafik Peningkatan Pemahaman Konsep Ukuran Berat Ringan Metode Eksperimen Siklus 1

Hasil siklus 1 menyatakan bahwa kemampuan memahami konsep ukuran berat ringan benda dengan metode eksperimen pada usia 3-4 tahun di PAUD Az-zaitun dinyatakan sudah mengalami 
Jurnal Warna : Jurnal Pendidikan Dan Pembelajaran Anak Usia dini. Maret 2019. Vol 04. No. 01

peningkatan namun belum menunjukkan keberhasilan, maka dari itu penelitian akan dilanjutkan pada tahap selanjutnya yaitu siklus 2.

\section{Hasil Pengamatan Siklus}

\section{Perencanaan}

Tindakan dalam siklus 2 ini dilakukan dalam 3 kali pertemuan, perencanaan diawali dengan meminta teman sejawat untuk dapat mengamati pada saaat penelitian tindakan kelas berlangsung. Rencana kegiatan siklus 2 pertemuan ke-1 yang direncanakan oleh peneliti adalah sebagai berikut :

1. Menentukan tema diriku dan subtema tubuhku serta topik bagian tubuh

2. Membuat RPPM dan RPPH

3. Menyiapkan berbagai media pembelajaran yaitu neraca sederhana, pasir dan wadahnya, balok dan lainlain

4. Membuat lembar observasi anak \& data hadir anak observasi penelitian

\section{Pelaksanaan}

Pelaksanaan kegiatan belajar mengajar siklus 2 pertemuan ke-1 dilaksanakan pada hari senin 23 juli 2018 di PAUD Az-zaitun pada anak kelompok B usia 3-4 tahun dengan jumlah anak sebanyak 12 orang. Pelaksanaan kegiatan dimulai dari pukul 07.30 sampai 09.30. Proses pembelajaran mengacu pada RPPH yang telah dipersiapkan sesuai dengan tema yaitu diriku sub tema tubuhku dan topik anggota tubuh. Peneliti mempersiapkan media pembelajaran yaitu balok, pasir serta neraca sederhana.

Observasi

Berdasarkan hasil pelaksanaan penelitian pada siklus 2 pada pertemuan 1 , 2 dan 3 berdasarkan aspek yang diamati dari 12 orang anak yang mengikuti pembelajaran diperoleh hasil sebagai berikut :

1. Pada siklus 2 pertemuan ke 1 , hasil pengamatan kemampuan memahami ukuran berat ringan dengan kategori berkembang sesuai harapan dan berkembang sangat baik, yaitu mampu membandingkan berat ringan berdasarkan ukuran terdapat 9 anak (75\%), mampu membandingkan ukuran berat ringan berdasarkan jenisnya terdapat 8 anak (66\%) dan mampu menyebutkan hasil ukuran berat ringan antara balok dan pasir terdapat 8 anak (66\%). Maka nilai keberhasilan pada siklus 2 pertemuan ke-1 adalah sebesar $69 \%$.

2. Pada siklus 2 pertemuan ke 2, hasil pengamatan kemampuan memahami ukuran berat ringan dengan kategori berkembang sesuai harapan dan berkembang sangat baik, yaitu mampu membandingkan berat ringan berdasarkan ukuran terdapat 10 anak (83\%), mampu membandingkan ukuran berat ringan berdasarkan jenisnya terdapat 10 anak (83\%) dan mempu menyebutkan hasil ukuran 
Jurnal Warna : Jurnal Pendidikan Dan Pembelajaran Anak Usia dini. Maret 2019. Vol 04. No. 01

\begin{tabular}{|c|c|c|c|c|c|c|}
\hline \multirow[t]{2}{*}{ No } & \multirow[t]{2}{*}{ Nama } & \multicolumn{3}{|c|}{$\begin{array}{c}\text { Aspek } \\
\text { penilaian }\end{array}$} & \multirow{2}{*}{$\begin{array}{c}\text { Juml } \\
\text { ah }\end{array}$} & \multirow[t]{2}{*}{ KT } \\
\hline & & 1 & 2 & 3 & & \\
\hline 1 & Alif & 4 & 4 & 4 & 12 & MB \\
\hline 2 & Zaidan & 3 & 3 & 3 & 9 & $\mathrm{BSH}$ \\
\hline 3 & Alvinna & 2 & 3 & 3 & 8 & MB \\
\hline 4 & Dzaky & 4 & 4 & 3 & 11 & $\mathrm{BSH}$ \\
\hline 5 & Farel & 3 & 2 & 2 & 7 & $\mathrm{MB}$ \\
\hline 6 & Kalila & 4 & 4 & 4 & 12 & $\mathrm{BSH}$ \\
\hline 7 & Revi & 4 & 4 & 3 & 11 & $\mathrm{MB}$ \\
\hline 8 & Risky & 2 & 3 & 3 & 8 & $\mathrm{MB}$ \\
\hline 9 & Najwa & 3 & 2 & 2 & 7 & MB \\
\hline 10 & Selvira & 4 & 3 & 3 & 10 & $\mathrm{BSH}$ \\
\hline 11 & Marsya & 3 & 3 & 3 & 9 & $\mathrm{BSH}$ \\
\hline 12 & Mahafis & 4 & 4 & 4 & 12 & $\mathrm{BSH}$ \\
\hline \multicolumn{2}{|c|}{$\begin{array}{l}\text { Jumlah } \\
\text { Skor } 3 \text { dan } 4\end{array}$} & 30 & 35 & 33 & & \multirow[b]{2}{*}{$83 \%$} \\
\hline \multicolumn{2}{|c|}{ Persentase } & $\begin{array}{l}83 \\
\%\end{array}$ & $\begin{array}{l}83 \\
\%\end{array}$ & $\begin{array}{l}83 \\
\%\end{array}$ & & \\
\hline \multicolumn{2}{|c|}{ Kategori } & \multicolumn{5}{|c|}{ Sangat Baik } \\
\hline
\end{tabular}

berat ringan antara balok dan pasir terdapat 9 anak (75\%). Maka nilai keberhasilan pada siklus 2 pertemuan ke-2 adalah sebesar $80 \%$.

3. Pada siklus 2 pertemuan ke 3, hasil pengamatan kemampuan memahami ukuran berat ringan dengan kategori berkembang sesuai harapan dan berkembang sangat baik, yaitu mampu membandingkan berat ringan berdasarkan ukuran terdapat 11 anak (91\%), mampu membandingkan ukuran berat ringan berdasarkan jenisnya terdapat 10 anak (83\%) dan mempu menyebutkan hasil ukuran berat ringan antara balok dan pasir terdapat 10 anak (83\%). Maka nilai keberhasilan pada siklus 1 pertemuan ke-3 adalah sebesar $85 \%$.

\section{Refleksi}

Berdasarkan hasil penelitian tindakan kelas siklus 2, menujukkan bahwa kemampuan anak memahami konsep ukuran berat ringan terus meningkat, dan sudah memenuhi atau mencapai batas ketuntasan sehingga penelitian tidak perlu dilanjutkan ke siklus berikutnya. Adapun hasil penelitian siklus 2 pertemuan ke 1,2, 3 sebagaimana dalam tabel rekaptulasi berikut ini :

Tabel .5 Rekaptulasi Kemampuan Memahami Konsep Ukuran Berat Ringan dengan Metode Eksperimen pada Siklus 2 Keterangan :

$1.81 \%-100 \%$ : Sangat baik

$2.61 \%-80 \% \quad$ : Baik

$3.41 \%-60 \%$ : Cukup

4. $21 \%-40 \%$ : Kurang

$5.0 \%-20 \% \quad$ : Kurang sekali

Tabel.6 Rekaptulasi Kemampuan Memahami Konsep Ukuran Berat Ringan dengan Metode Eksperimen Siklus 2

\begin{tabular}{|c|c|c|c|c|c|}
\hline No & $\begin{array}{l}\text { Aspek yang } \\
\text { dinilai }\end{array}$ & P1 & $\mathrm{P} 2$ & P3 & $\begin{array}{c}\text { Nilai } \\
\text { rata- } \\
\text { rata }\end{array}$ \\
\hline 1 & $\begin{array}{l}\text { Mampu } \\
\text { Membandingkan } \\
\text { berat ringan } \\
\text { benda berdasarkan } \\
\text { ukurannya }\end{array}$ & $\begin{array}{l}75 \\
\%\end{array}$ & $\begin{array}{l}83 \\
\%\end{array}$ & $\begin{array}{l}91 \\
\%\end{array}$ & $83 \%$ \\
\hline 2 & $\begin{array}{l}\text { Mampu } \\
\text { Membandingkan } \\
\text { berat ringan } \\
\text { berdasarkan } \\
\text { jenisnya }\end{array}$ & $\begin{array}{l}66 \\
\%\end{array}$ & $\begin{array}{l}83 \\
\%\end{array}$ & $\begin{array}{l}83 \\
\%\end{array}$ & $77 \%$ \\
\hline 3 & $\begin{array}{l}\text { Mampu } \\
\text { menyebutkan } \\
\text { hasil ukuran berat- } \\
\text { ringan antara } \\
\text { balok dan pasir } \\
\text { dengan tepat }\end{array}$ & $\begin{array}{l}69 \\
\%\end{array}$ & $\begin{array}{l}75 \\
\%\end{array}$ & $\begin{array}{l}83 \\
\%\end{array}$ & $76 \%$ \\
\hline & \multicolumn{4}{|c|}{ Nilai ketuntasan siklus 2} & $79 \%$ \\
\hline
\end{tabular}

Aspek penilaian dan proses pemebelajaran siklus 2 sebagai berikut :

1. Peningkatan kemampuan membandingkan berat ringan berdasarkan ukuran mencapai nilai 
Jurnal Warna : Jurnal Pendidikan Dan Pembelajaran Anak Usia dini. Maret 2019. Vol 04. No. 01

rata-rata $83 \%$. Hal ini menunjukkan bahwa kemampuan anak memahami konsep berat ringan berdasarkan ukuran berat ringan suatu benda dilihat dari bentuknya besar atau kecil melalui kegiatan eksperimen dikategorikan sangat baik.

2. Peningkatan kemampuan membandingkan ukuran berat ringan berdasarkan jenisnya mencapai $77 \%$. Hal ini menunjukkan bahwa kemampuan anak memahami konsep berat ringan berdasarkan jenisnya dilihat dari bahan benda tersebut digunakan melalui kegiatan eksperimen dikategorikan baik.

3. Peningkatan kemampuan menyebutkan hasil ukuran berat- ringan antara balok dan pasir dengan tepat mencapai $76 \%$. Hal ini menunjukkan bahwa kemampuan anak memahami konsep berat ringan dengan menyebutkan hasil ukuran berat ringannya dengan menggunakan neraca maupun tanpa neraca dikategorikan Baik.

Dari data hasil pada tabel dapat digambarkan pada grafik dibawah ini :

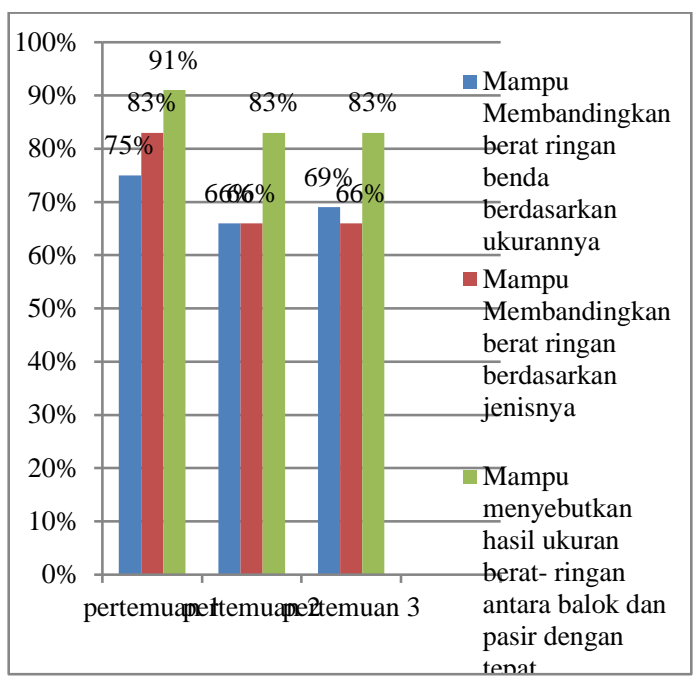

Grafik .2 Kemampuan Memahami Konsep Berat Ringan Metode Eksperimen Siklus 2

Dari hasil penelitian kemampuan memahami kosep berat ringan melalui metode eksperimen meningkat dan mencapai nilai ketuntasan sebesar $79 \%$. Peningkatan Pemahaman konsep ukuran berat ringan melalui metode eksperimen antar siklus dapat dilihat pada grafik berikut ini :

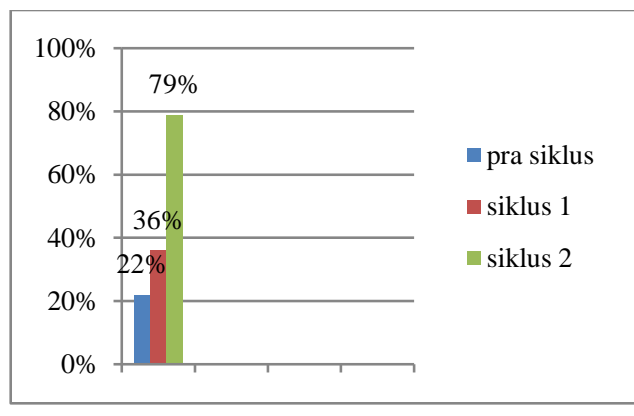

Grafik.3 Kemampuan Memahami Konsep

Ukuran Berat Ringan Metode Eksperimen

Antar siklus

\section{Pembahasan Hasil Penelitian}

Berdasarkan pelaksanaan penelitian tindakan kelas dari tahapan siklus 1 dan siklus 2, menunjukkan bahwa hasil penelitian tindakan kelas untuk 
Jurnal Warna : Jurnal Pendidikan Dan Pembelajaran Anak Usia dini. Maret 2019. Vol 04. No. 01

meningkatkan pemahaman konsep ukuran berat ringan benda melalui metode eksperimen pada anak usia 3-4 tahun di PAUD Az-zaitun mengalami peningkatan, berikut uraiannya :

1. Meningkatnya kemampuan memahami konsep ukuran berat ringan benda dilihat berdasarkan ukurannya yaitu besar atau kecil pada siklus 1 mencapai nilai rata-rata 41\%, kemudian pada siklus 2 meningkat hingga mencapai nilai $83 \%$.

2. Meningkatnya kemampuan memahami konsep ukuran berat ringan benda dilihat berdasarkan jenisnya yaitu dengan membandingkan benda berdasarkan jenis bahan dari benda itu terbuat/berasal seperti membandingkan berat ringan antara pasir dengan kayu balok atau pensil yang terbuat dari plastik dengan tempat/ kotak pensil yang terbuat dari besi. Pada siklus 1 nilai rata-rata yang dicapai adalah sebesar 35\% kemudian pada siklus ke 2 naik hingga mencapai $77 \%$.

3. Meningkatnya kemampuan anak dalam menyebutkan hasil ukuran berat- ringan antara balok dan pasir dengan tepat baik itu dengan menebak secara langsung maupun dengan menggunakan neraca sederhana yang pada siklus 1 mencapai nilai rata-rata $35 \%$ kemudian pada siklus 2 meningkat hingga $76 \%$.

Hal tersebut dapat dicapai atau terjadi peningkatan dikarenakan metode pembelajaran yang digunakan adalah metode eksperimen dimana anak-anak ikut terlibat secara langsung dalam pembelajaran tersebut secara mandiri maupn berkelompok sehingga mereka akan lebih mudah cepat paham tentang apa yang mereka sedang pelajari dan lebih dapat mengingat apa yang telah dijelaskan oleh guru serta contoh-contoh yang telah diberikan yang kemudian akan dibuktikan bersama-sama melalui percobaan secara langsung. Ini sesuai dengan tata cara Metode eksperimen sendiri adalah metode pembelajaran yang memberikan kesempatan kepada anak didik, baik perorangan atau kelompok, untuk dilatih melakukan suatu proses atau percobaan. Mulyani Sumantri menyatakan bahwa Metode eksperimen atau percobaan diartikan sebagai cara belajar mengajar yang melibatkan anak didik dengan mengalami dan membuktikan sendiri proses dan hasil percobaan itu (Maria 2014). Melalui metode ini anak didik diharapkan dapat sepenuhnya terlibat dalam perencanaan eksperimen, melakukan, menemukan fakta, mengumpulkan data, mengendalikan variabel, dan memecahkan masalah yang dihadapinya secara nyata.

Kelemahan dari proses penelitian tindakan kelas ini menggunakan metode 
Jurnal Warna : Jurnal Pendidikan Dan Pembelajaran Anak Usia dini. Maret 2019. Vol 04. No. 01

eksperimen bahwa tidak dapat dilakukan oleh anak-anak dalam jangka waktu bersamaan karena kurangnya ketersediaan dari alat penelitian seperti neraca dan kayu balok sehingga anak yang menunggu giliran kadang - kadang tidak sabar dan merebut giliran temannya, suasana kelas kadang menjadi sedikit riuh karena beberapa anak lainnya ada yang tidak fokus dalam proses pembelajaran dan hanya bermain bersama teman lainnya atau berebut tempat duduk untuk melihat temannya yang sedang melakukan percobaan. Namun hal tersebut sedikit dapat diatasi dengan cara saat melakukan percobaan anak-anak disuruh duduk membentuk baris setengah lingkaran sehingga jika ada temannya yang maju anak yang lainnya akan memperhatikan temannya tersebut dan tidak berebut tempat duduk.

Pembelajaran mengenai pemahaman konsep berat ringan pada anak usai dini sseperti ini yaitu menggunakan metode eksperimen itu sendiri saat ini jarang dilakukan oleh guru, karena memang biasanya di sekolah-sekolah tidak tersedianya alat-alat yang digunakan untuk menunjang kegiatan tersebut seperti ketersediaan neraca dimana proses pembelajarannya sendiri hanya berfokus dari penjelasan guru saja, oleh karena itu peneliti tertarik untuk mengenalkan cara memahami dan membedakan ukuran berat ringan suatu benda dengan bereksperimen secara langsung kepada anak-anak kelompok B usia 3-4 tahun di PAUD Azzaitun, selain itu materi ini akan bermanfaat untuk memberikan gambaran atau melatih kemampuan/potensi anak menguasai suatu keahlian yaitu anak dapat membedakan berat dan ringan suatu benda tanpa beranggapan bahwa benda besar memiliki beban yang lebih berat dan benda yang jumlahnya banyak memiliki beban yang lebih berat. Sehingga dengan adanya kemampuan membedakan ini merupakan hasil yang didapat dapat menjadi suatu kecakapan anak mengetahui tentang ketidaksamaan sesuatu hal secara mudah.

Adapun hasil dari penelitian tindakan kelas yang telah dilaksanakan melalui 2 siklus dapat diperoleh hasil siklus 1 dan 2 . Pada siklus 1 dapat diperoleh hasil dengan nilai rata-rata $36 \%$ termasuk dalam kategori kurang, hal ini didapat dari hasil pengamatan kemampuan anak yang dapat dipengaruhi karena anak belum terbiasa dengan suasana belajar disekolah dan masih merasa takut dengan guru maupun teman temannya disekolah sehingga anak kurang konsentrasi dalam mendengarkan maupun memperhatikan guru kemudian saat penelitian dilanjutkan pada siklus ke-2 terjadi peningkatan dengan nilai rata-rata 79\% karena siswa sudah terbiasa dengan pembelajaran disekolah dan keadaan dilingkungan sekolah sehingga materi mengenai konsep berat ringan dapat cukup diterima dan dipahami oleh siswa selain itu karena metode yang digunakan merupakan 
Jurnal Warna : Jurnal Pendidikan Dan Pembelajaran Anak Usia dini. Maret 2019. Vol 04. No. 01

metode eksperimen sehingga metode pembelajaran lebih dapat bervariasi dan menyenangkan. Hal ini membuktikan bahwa melalui metode eksperimen dapat meningkatkan pemahaman konsep ukuran berat ringan pada anak usia 3-4 tahun di PAUD Az-zaitun Genting Tanah.

\section{PENUTUP}

\section{Kesimpulan}

Penelitian tindakan kelas ini menyimpulkan bahwa dengan metode eksperimen dapat meningkatkan pemahaman konsep ukuran berat ringan pada anak kelompok B usia 3-4 tahun di PAUD Az-zaitun genting Tanah tahun pembelajaran 2018-2019. Hal ini ditandai oleh peningkatan persentase hasil belajar, yaitu sebagai berikut :

1. Peningkatan pemahaman konseup ukuran berat ringan pada kondisi prasiklus yaitu kemampuan membandingkan ukuran berat ringan benda berdasarkan ukurannya sebesar $25 \%$, membandingkan ukuran berat ringan benda berdasarkan jenisnya sebesar $25 \%$ dan menyebutkan hasil ukuran berat- ringan antara balok dan pasir dengan tepat sebesar $16 \%$.

2. Peningkatan pemahaman konseup ukuran berat ringan pada siklus 1 yaitu kemampuan membandingkan ukuran berat ringan benda berdasarkan ukurannya sebesar 41\%, membandingkan ukuran berat ringan benda berdasarkan jenisnya sebesar
$35 \%$ dan menyebutkan hasil ukuran berat- ringan antara balok dan pasir dengan tepat sebesar 33\%.

3. Pemahaman konseup ukuran berat ringan pada kondisi prasiklus yaitu kemampuan membandingkan ukuran berat ringan benda berdasarkan ukurannya sebesar $83 \%$, membandingkan ukuran berat ringan benda berdasarkan jenisnya sebesar $77 \%$ dan menyebutkan hasil ukuran berat- ringan antara balok dan pasir dengan tepat sebesar $76 \%$.

Sehingga dapat disimpulkan bahwa peningkatan pemahaman konsep ukuran berat ringan pada anak usia 3-4 tahun di PAUD Az-zaitun Genting Tanah tahun pembelajaran 2018/12019 dapat ditingkatkan melalui metode eksperimen dengan nilai ketuntasan $79 \%$ yang termasuk dalam kategori aik karena dengan pembelajaran menggunakan metode eksperimen siswa dapat sepenuhnya terlibat dalam perencanaan eksperimen, melakukan, menemukan fakta, mengumpulkan data, dan memecahkan masalah yang dihadapinya secara nyata yang akan membuat proses belajar tentunya lebih menyenangkan dan bervariasi serta menambah ketertarikan minat anak dalam meningkatkan pemahaman konsep ukuran berat ringan.

\section{Saran}

1. Bagi kepala sekolah PAUD Azzaitun diharapkan lebih memberikan 
Jurnal Warna : Jurnal Pendidikan Dan Pembelajaran Anak Usia dini. Maret 2019. Vol 04. No. 01

motivasi kepada guru agar lebih baik dalam membuat perangkat mengajar dalam menentukan metode, media dan alat peraga yang tepat guna serta mudah dipergunakan oleh anak didik

2. Bagi guru/pendidik diharapkan agar selalu meningkatkan mutu dalam kegiatan belajar mengajar serta aktif dan kreatif dalam menyiapkan media pembelajaran yang mampu menarik minat belajar anak dalam meningkatkan kemampuan memahami konsep ukuran berat ringan.

3. Bagi anak agar lebih mengembangkan kemampuan berfikir, menumbuhkan kreativitas dan mampu bersosialisasi dengan

\section{DAFTAR PUSTAKA}

Kemampuan, Meningkatkan, Pemahaman Konsep, Satuan Berat, Melalui Media, Puzzle Kotak, Bagi Anak, Dikelas Iv, and Kota Payakumbuh. 2016. "E-JUPEKhu." 5.

Lestariningrum, Anik and Nuryanti. 2016. "SAINS PADA ANAK DIDIK KELOMPOK A TK PKK SURUHWADANG KECAMATAN Kademangan Kabupaten Blitar." Educhild 5(1):46-50.

Maria, Leni. 2014. "Penggunaan Metode Eksperimen Untuk Meningkatkan Hasil Belajar Siswa Kelas V SDN \$\# Tapis Tembawang." 3.

Nopayana, Siska, Deti Rostika, Helmi Ismail, Lambang Bilangan, and Media Papan. n.d. "Upava Meningkatkan Pemahaman Konsep Bilangan Beserta Lambang Bilangan Pada Anak Melalui Media Papan Flanel Modifikasi."
Pendidikan, Jurusan, Guru Pendidikan, Anak Usia, Dini Volume, No Tahun, Penerapan Permainan, Tradisional Dengkleng, Jurusan Pendidikan, Guru Pendidikan, Anak Usia, Dini Volume, No Tahun, Meningkatkan Keterampilan, Sosial Melalui, Jurusan Pendidikan, Guru Pendidikan, Anak Usia, Dini Volume, No Tahun, Kemampuan Kognitif, Anak Usia, I. Gusti Ayu, Sri Purnami, I. Ketut Gading, Mutiara Magta, Jurusan Pendidikan, Guru Pendidikan, Anak Usia, Dini Volume, and No Tahun. 2017.

"PENERAPAN METODE EKSPERIMEN UNTUK MENINGKATKAN TK SAIWA DHARMA Jurusan Bimbingan Konseling Fakultas Ilmu Pendidikan Universitas Pendidikan Ganesha Abstrak E-Journal Pendidikan Anak Usia Dini Universitas Pendidikan Ganesha.” 4(3).

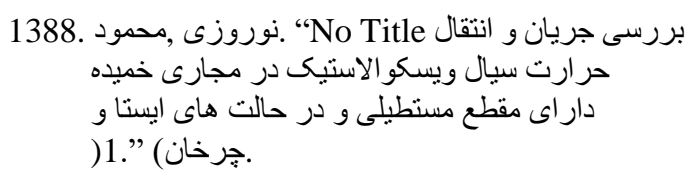

Faidatun, Nugraheni. 2013. Upaya Peningkatan Pengenalan Pengetahuan Peristiwa Alam Melalui Metode Eksperimen Pada Anak Kelompok B TK Adinda Mojolaban Sukoharjo Tahun 2012/2013.

Diakses dari https://eprints.uns.ac.id/12092/ pada tanggal 15 januari 2018 pukul 08.30 WIB

Haryono, 2015. Bimbingan Teknis Penelitian Tindakan Kelas. Yogyakarta: Amara Books

MS, Sumantri. 2005. Model Pengembangan Keterampilan Motorik Anak Usia Dini. Jakarta: Depdiknas

Nisa, N. Afifatun. 2015. Upaya Meningkatkan Kemampuan Membedakan Konsep Berat Ringan dengan Metode Eksperimen Menakar dan Menimbang Biji-Bijian pada Siswa Kelompok B TK YWKA Kecamatan Purwokerto. 
Jurnal Warna : Jurnal Pendidikan Dan Pembelajaran Anak Usia dini. Maret 2019. Vol 04. No. 01

Diakses

dari

http://repository.ump.ac.id/2032/1/NU

RUL\%20AFIF0COVER.pdf pada

tanggal 15 januari 2018 pukul 08.00 WIB

Nugraha, Ali. 2005. Pengembangan Pembelajaran Sains pada Anak Usia Dini. Jakarta: Depdiknas

Peraturan Menteri Pendidikan Nasional Nomor 58 Tahun 2009

Slamet, Suyanto. 2005. Dasar- Dasar Pendidikan Anak Usia Dini. Yogyakarta : Hikayat Publishing.

Suharsimi, Arikunto. 2010. Penelitian Tindakan Kelas. Yogyakarta: Aditya Media
Suharto dan Tata Iryanto. 2004. Perkembangan Belajar Anak Usia Dini. Surabaya : Indah

Sujiono, Anas. 2005. Pengantar Statistik Pendidikan. Jakarta : Raja G. Persada

Undang-Undang Nomor 23 Tahun 2003 tentang Sistem Pendidikan Nasional 